\title{
MAPPING OF ANDROID-BASED INDUSTRIAL ESTATE DEVELOPMENT
}

\author{
Jelita Citrawati Jihan andA. A. Sagung A W
}

\begin{abstract}
The industrial sector is one of the most important sectors and strategies in development as the lifeblood of the economy. The development of this sector was aimed at mobilizing regional potentials, increasing accessibility and mobility of the community, and increasing urban productivity.

Mapping of industrial estate on labor availability parameters, physical characteristics (soil type, slope of soil, and erosion prone areas), availability of facilities and infrastructure, accessibility, and government policies for determining the location of industrial estate in East Surabaya Development Unit I used a Geographic Information System.

The mapping of industrial estate used Geographic Information System approach with the overlay and buffer methods. The data were obtained from ground truth measurements of industrial location determination i.e. maps and position data, coordinates, spatial and spatial, with surveys based on observations to GNSS satellites. This research used Hyper Text Markup Language (HTML) programming language to build the site displays of various mapping information of industrial area.
\end{abstract}

Keywords.Mapping, Industry, HyperText Markup Language (HTML), Android

\section{Introduction}

Surabaya is the center of industrial activities in the eastern part of Indonesia and the second largest city in Indonesia after Jakarta. The city has been making its progress quite rapidly. The developing regions are indicated by an increase in growth or development as a result of various business activities, by both government and private sectors which are basically aimed at improving the fulfillment of needs (Sholikhah, 2012)

Industrial areas in eastern Surabaya spatially have strategic locations for trade activities. The strategic locations and the existence of several parameters will affect the development in the SIER Industrial Surabaya area so that the main attraction in the economic field increase trading activities using geographic information system technology.

The purpose of this study was to assess the mapping of industrial development and growth of infrastructure facilities around the area, therefore it is not just as an android-based industrial area. As an industrial and warehousing complex, the area will also be equipped with shopping centers, commerce, including apartments, hospitals and hotels.

\section{The main content \\ Research Problem Formulation}

The problem of this research is formulated as follows: "How is the description and process of the mapping of industrial estate for the management of the industrial estate in East Surabaya with the development of the Geographic Information System (GIS) based on Android"

The study area used in this research coveredthe area of Development Unit (UP) 1 of Rungkut Tenggilismejoyo, and Gununganyar Districts. 


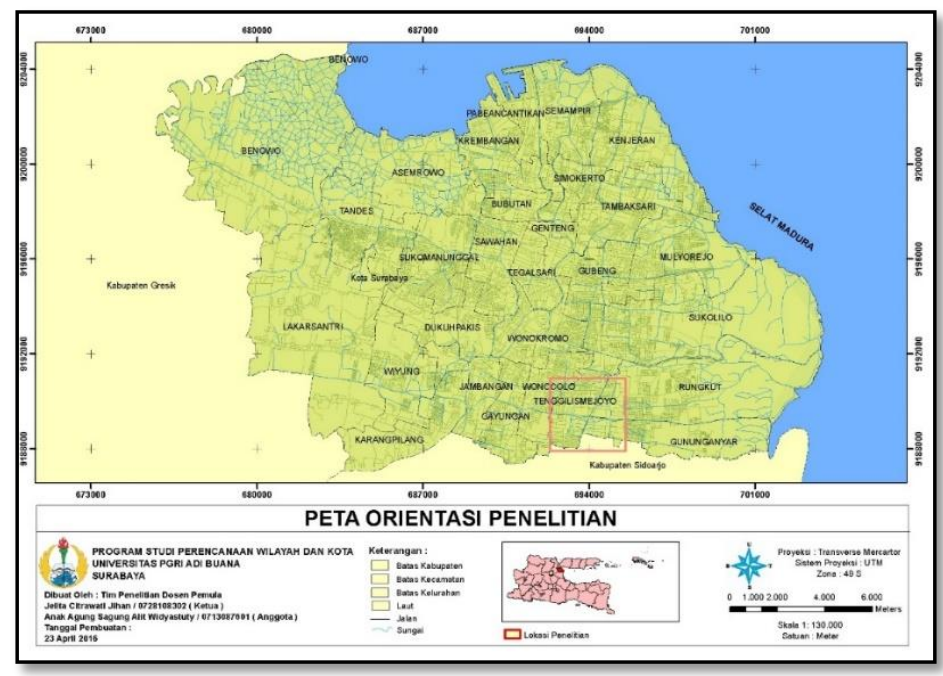

Figure 1 Research Site

Source: Analysis, 2016

Geographical Location and Boundary of Research Area

The Rungkut industrial area is geographically located in the South Latitude between $7^{\circ} 19^{\prime}-7^{\circ}$ $20^{\prime}$ and East Longitude between $112^{\circ} 44^{\prime}-112^{\circ} 45^{\prime}$. Administratively SIER is part of UP 1 of East Surabaya. The Development Unit I of Rungkut covers Rungkut, Gunung Anyar, and Tenggilis Mejoyo Districts. Their boundaries are as follows:

1. The northern part is adjacent to Sukolilo District.

2. Southern part borders with Sidoarjo regency.

3. Eastern boundary borders Madura Strait.

4. The western boundary borders Wonocolo District.

The analysis included:

a. Map processing using the Geographic Information System

b. The Android program application for mapping the industrial area was through the HyperText Markup Language (HTML) programming language.

\section{Purpose}

The purpose of this study was to describe and present the design of industrial areas and their attributes to the determination of industrial location in the area of UP 1 of East Surabaya based on the mobile Geographic Information System (GIS).

The benefits of this research were to be one of the media to facilitate the display of information to industries that stand in the area. This was inteded to keep the area from the adverse effects of industrial activities.

\section{Geospatial roadmap}

The Android-based Geographic Information System can be one of the most mobile interactive tools. The GIS facilitates to describe the location of the public facilities on the real condition in this case the map which the mobile phones (Android) brings about. Here we will get an analysis and visualization that can be used as a reference for the users. 


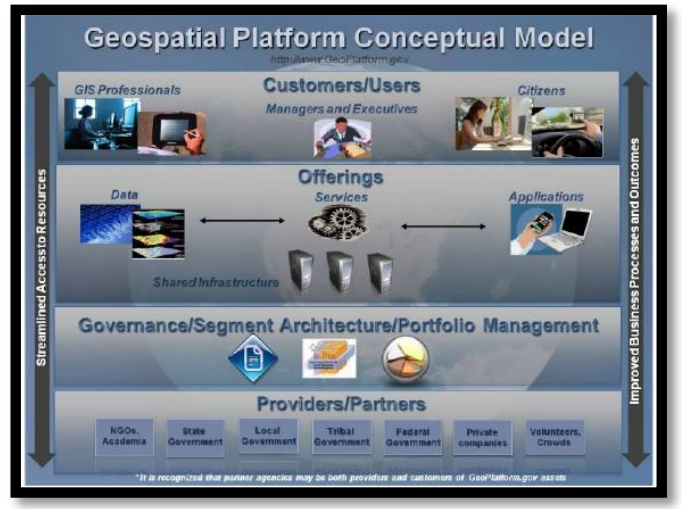

Figure 2. Basic Concepts of Geospatial Data

Source: Geospatial Platform Modernization Roadmap v4 Final - March 2011

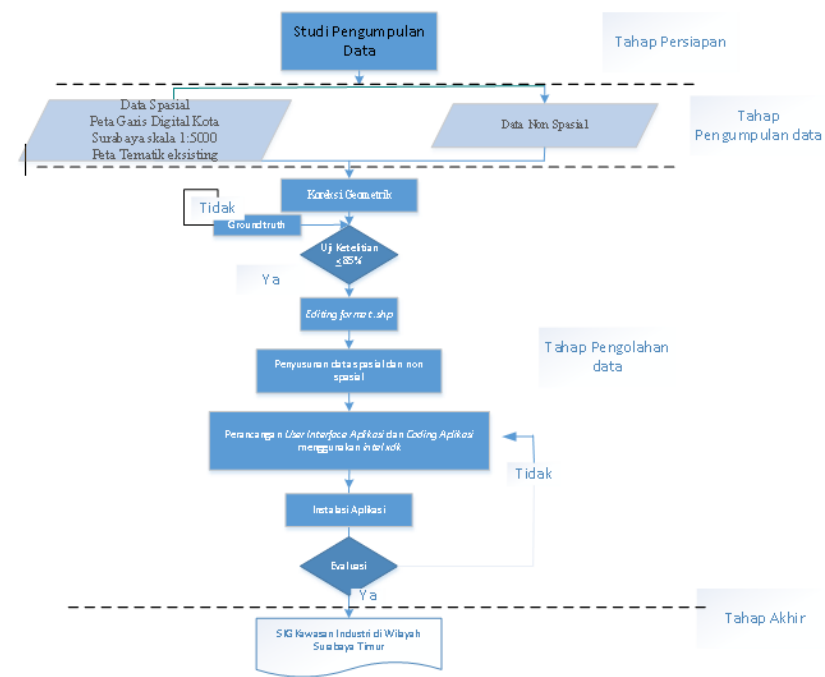

Figure 3. Data Flow Chart

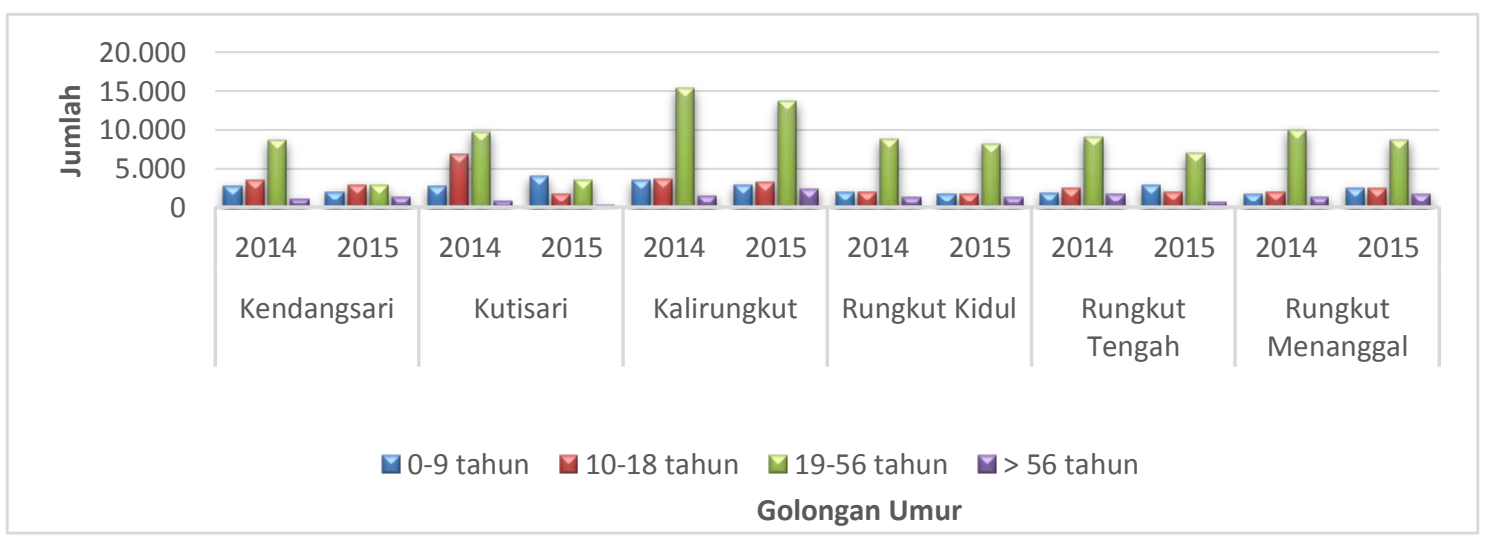

Figure 4. Graph of Population Development in Rungkut Industrial Area of Surabaya in 2014-2015 
In Indonesia, the labor force that plays a role in the workforce is a population aged 10 years and over who are actively engaged in economic activities (Central Bureau of Statistics, 1983, in Mantra, 2000). The productive age population (15-64 years old) and non productive men and women can describe work in a region. Potential labor force for skilled workers is shown by the level of senior secondary education required by warehousing operations. The following table presents a comparison of productive and non-productive age:

Table 1 Productive and Non-productive Age of each Subdistricts of

\begin{tabular}{|c|c|c|c|}
\hline \multicolumn{4}{|c|}{ Rungkut Industri Surabaya } \\
\hline Sub-districts & $\begin{array}{c}\text { Non } \\
\text { Productive } \\
\text { Age (person) }\end{array}$ & $\begin{array}{c}\text { Productive } \\
\text { Age } \\
\text { (person) }\end{array}$ & Total \\
\hline Kendangsari & 6.211 & 2.876 & 9.087 \\
\hline Kutisari & 6.048 & 3.508 & 9.556 \\
\hline Kalirungkut & 8.519 & 13.720 & 22.239 \\
\hline Rungkut Kidul & 4.742 & 8.206 & 12.948 \\
\hline Rungkut Tengah & 5.477 & 6.984 & 12.461 \\
\hline Rungkut Menanggal & 6.611 & 8.606 & 12.720 \\
\hline
\end{tabular}

Source: Data Profil, 2017.

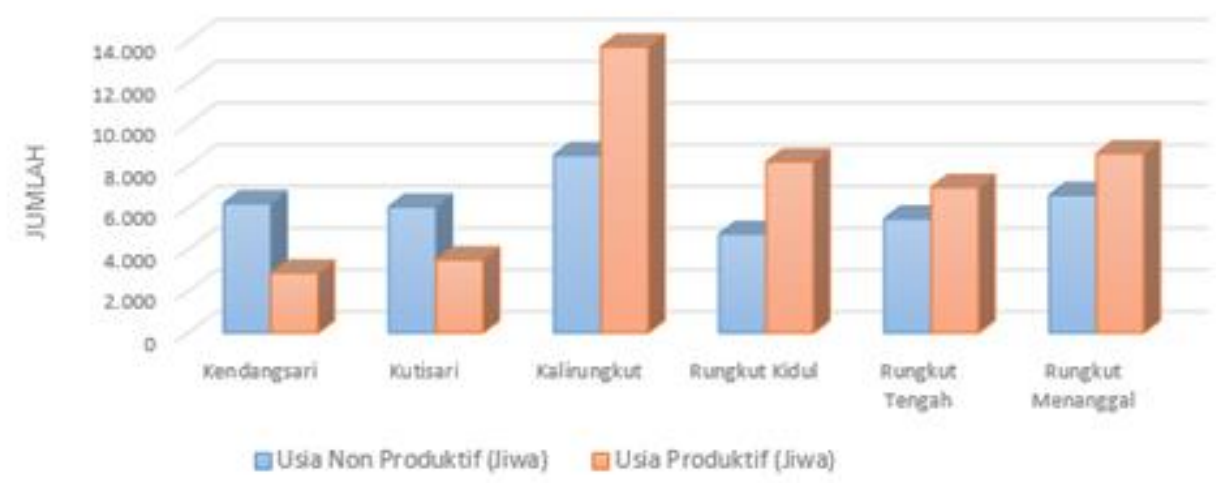

Figure 5. Productive and Non-Productive Age of Each Subdistrict of Rungkut Industri Surabaya in 2014-2015

Facilities and infrastructure supporting industrial parks in SIER include road, electricity, water, transportation networks. 


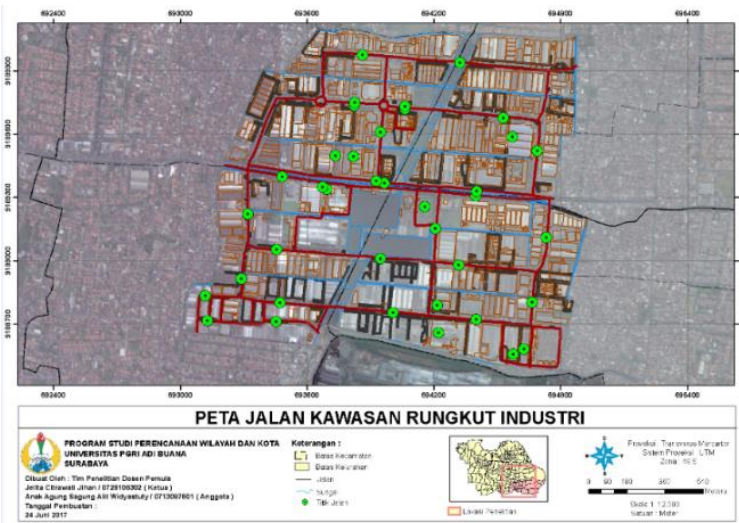

Figure 6 Map of roads of SIER Surabaya

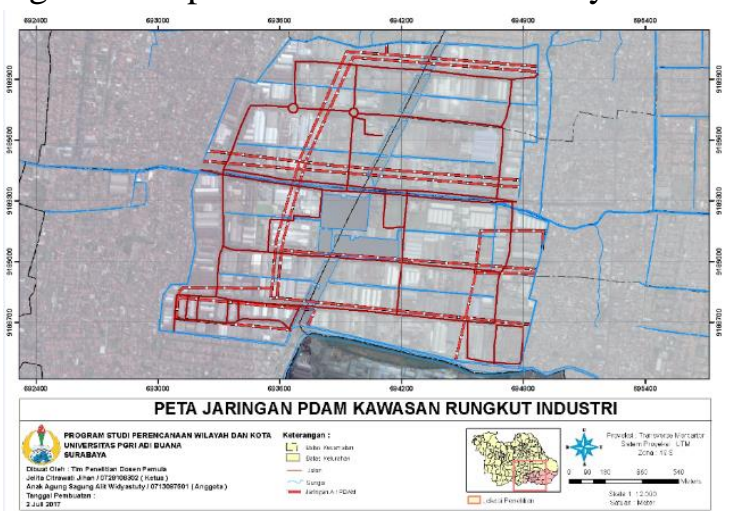

Figure 8. Map of water networks

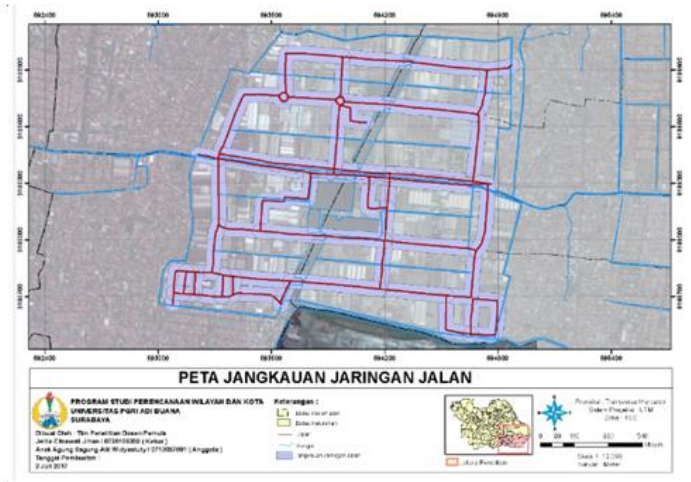

Figure 10. Map of range of road networks

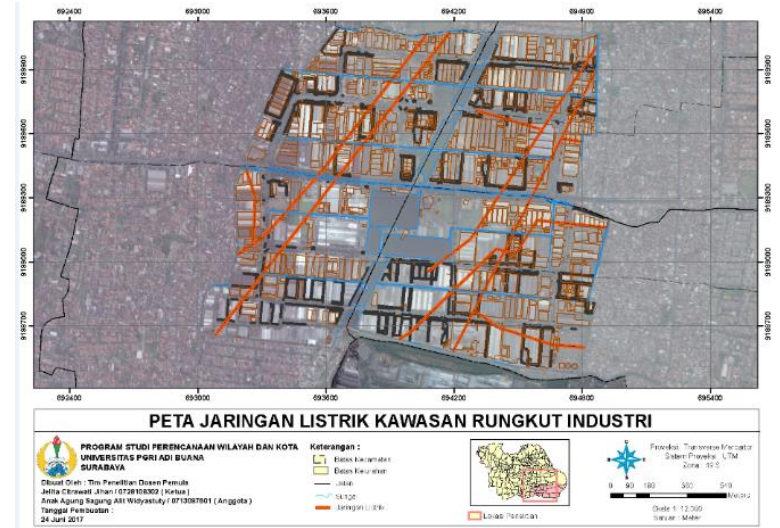

Figure 7. Map of electricity networks

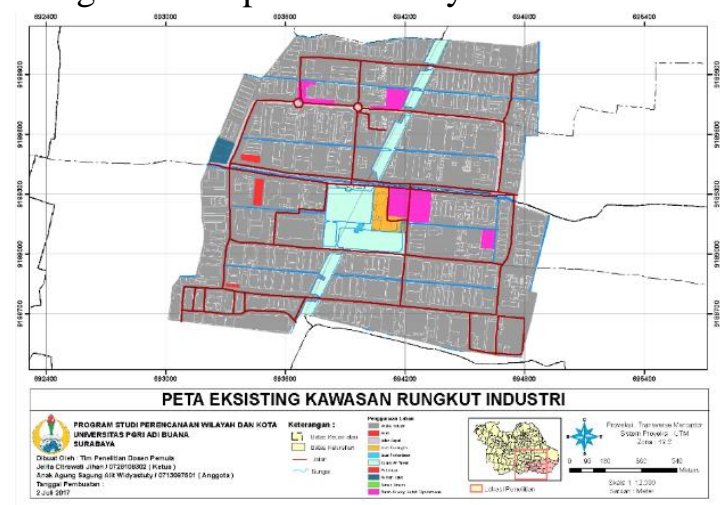

Figure 9. Map of the existing research sites

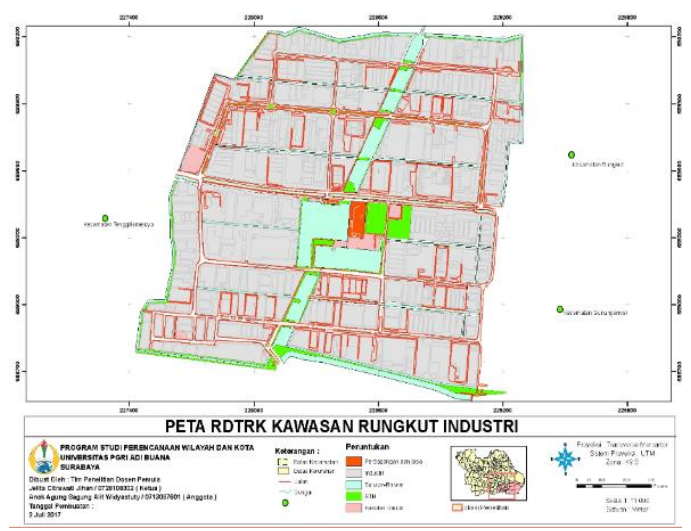

Figure 11. Map of RDTRK

From the calculations of accuracy, in the test of 19 sample points -4 point sample errors $=16$ sample points. $\mathrm{KI}=16 / 19 \times 100 \%=84.21 \%$ so the accuracy was acceptable. The result of accuracy is accepted if the interpretation meets tolerance of above $80 \%$ according to Anderson (1971).

The next stage of scoring for each variable was to determine the level of land suitability of warehousing area parameters derived from Junaedi in Analysis of Industrial Zones In Dati II Kulonprogo, 1986. 
Ground Truth

a. Street

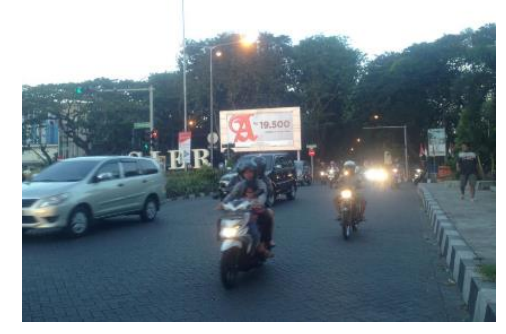

Located on the coordinates (693249 9189490) m . The location of the photograph is on Rungkut Raya Street

b. Fasilitas Umum

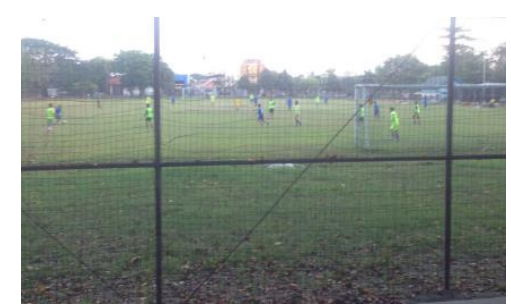

Located on the coordinates (694148 9189307) $\mathrm{m}$. The location of the photo shoot is in front of Football Field Jl. Rungkut Industri Raya

c. Lahan Kosong

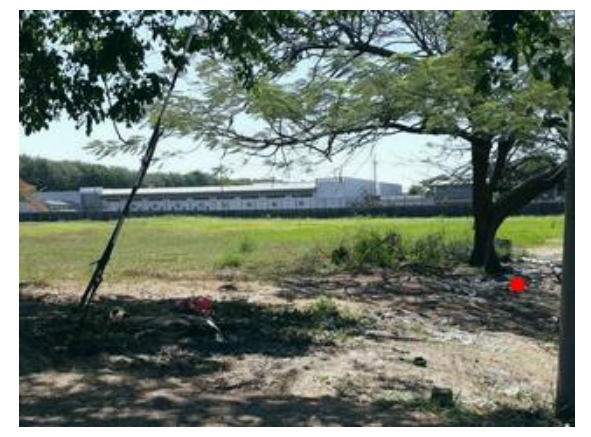

Located on the coordinates (694289 9189324) $\mathrm{m}$. The location of the shooting is next to the SIER headquarters 


\section{d. Hotel}

Located on the coordinates (693528 9189356) $\mathrm{m}$. Location of shooting from the east side is on Jl. Rungkut Industri 3.

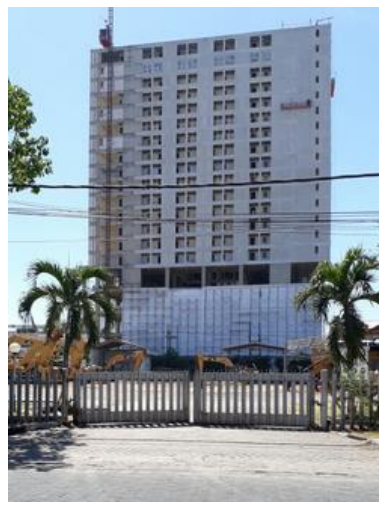

e. Sungai / Saluran

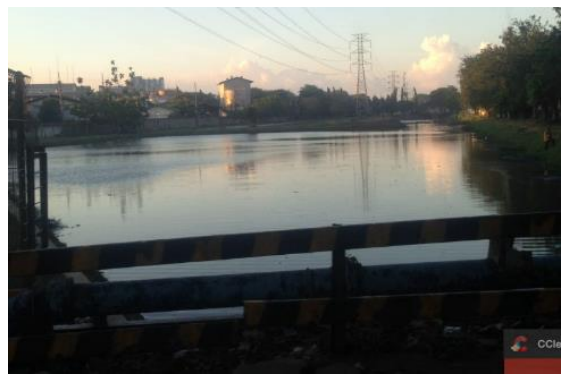

Located on the coordinates (694233 9189724) m . The location of the photo taking is at Rungkut Industri I

\section{f. Lahan Industri/ Gudang}

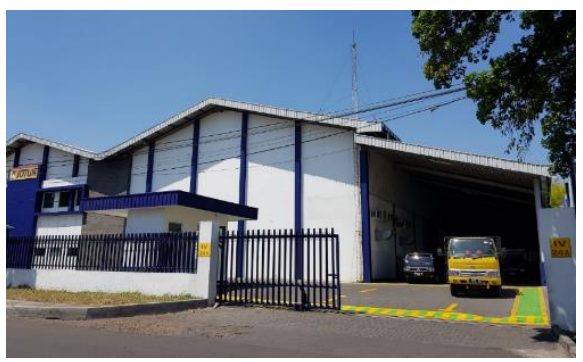

Located on the coordinates (694289 9189324) $\mathrm{m}$. Location of shooting in the complex area of industrial area. 
Table 2. Parameter of Rungkut Industrial Warehousing Area

Criteria - Classifications Analysis Results

\begin{tabular}{|c|c|c|c|c|}
\hline \multicolumn{5}{|c|}{ A.Physical Characteristics } \\
\hline 1 & Type of non-productive soil for a & & & \\
\hline $\mathrm{a}$ & $\begin{array}{l}\text { Type of Aluvial classification: } \\
\text { improper }\end{array}$ & 1 & 1 & \multirow{3}{*}{$\begin{array}{l}\text { The industrial wrap contains alluvial } \\
\text { hydromort then it does not correspond } \\
\text { to the industrial estate so the value is } 1\end{array}$} \\
\hline $\mathrm{b}$ & $\begin{array}{l}\text { Type of Regosal classification: } \\
\text { proper }\end{array}$ & \multicolumn{2}{|l|}{3} & \\
\hline $\mathrm{c}$ & $\begin{array}{l}\text { Type Kambisol Classification: } \\
\text { very proper }\end{array}$ & \multicolumn{2}{|c|}{5} & \\
\hline 2 & \multicolumn{4}{|c|}{ Slope of the ground, i.e. slope of $<8 \%$ is supporting (devided by area per district) } \\
\hline $\mathrm{a}$ & $<30 \%$ classification: not proper & \multicolumn{2}{|c|}{1} & \multirow{3}{*}{$\begin{array}{l}\text { For the slope of industrial land } \\
\text { Rungkut with score } 5 \text { due to the slope } \\
\text { of the land } 0-4 \%\end{array}$} \\
\hline $\mathrm{b}$ & 30-60\% classification: proper & \multicolumn{2}{|l|}{3} & \\
\hline $\mathrm{c}$ & $>60 \%$ classification: very proper & 5 & 5 & \\
\hline 3 & \multicolumn{3}{|l|}{ Areas prone to erosion cover: } & \\
\hline $\mathrm{a}$ & $\begin{array}{l}\text { Severe erosion classification: not } \\
\text { proper }\end{array}$ & 1 & & \multirow[t]{3}{*}{$\begin{array}{l}\text { The industrial area of Rungkut earned } \\
\text { a score of } 5 \text { no erosion. }\end{array}$} \\
\hline $\mathrm{b}$ & $\begin{array}{l}\text { Mild erosion classification: } \\
\text { proper }\end{array}$ & 3 & & \\
\hline $\mathrm{c}$ & $\begin{array}{l}\text { No erosion classification: very } \\
\text { proper }\end{array}$ & 5 & 5 & \\
\hline \multicolumn{5}{|c|}{ B. Work Force Availability of Working Age Population of 15-64 years } \\
\hline a & $\begin{array}{l}17,000 \text { persons classification: not } \\
\text { proper }\end{array}$ & 1 & & \multirow{3}{*}{$\begin{array}{l}\text { Manpower requirements } 43,900 \\
\text { persons in SIER meet the } \\
\text { classification of 'very proper' both } \\
\text { from the region and outside. }\end{array}$} \\
\hline $\mathrm{b}$ & $\begin{array}{l}17,000 \text { to } 20,000 \text { persons } \\
\text { classification: } p r o p e r\end{array}$ & 3 & & \\
\hline c & $\begin{array}{l}>20,000 \text { persons classification: } \\
\text { very proper }\end{array}$ & 5 & 5 & \\
\hline \multicolumn{5}{|c|}{ C. Accessibility of roads with criteria : } \\
\hline & $\begin{array}{l}100 \mathrm{~km} / \mathrm{ha} \text { classification: not } \\
\text { proper }\end{array}$ & 1 & 1 & \multirow{3}{*}{$\begin{array}{l}\text { The values obtained through the } \\
\text { entire length of the road divided by } \\
\text { the area of each district. The result of } \\
\text { industrial road length of } 88.87 \mathrm{~km} \\
\text { was divided into } 3,570 \text { ha sub- } \\
\text { districts of } 0.02 \mathrm{~km} / \mathrm{ha} \text {. It shows that } \\
\text { it was less than } 100 \mathrm{~km} / \mathrm{ha} \text {, the } \\
\text { variable does not match the score } 1 \text {. }\end{array}$} \\
\hline $\mathrm{b}$ & $\begin{array}{l}100-200 \mathrm{~km} / \mathrm{ha} \text { classification: } \\
\text { proper }\end{array}$ & 3 & & \\
\hline & $\begin{array}{l}>200 \mathrm{~km} / \mathrm{ha} \text { classification: } \\
\text { proper }\end{array}$ & 5 & & \\
\hline \multicolumn{5}{|c|}{ D. Availabiity of Facilities } \\
\hline $\mathrm{a}$ & No facilities & 1 & & \multirow{2}{*}{$\begin{array}{l}\text { For accessibility the given value was } \\
5 \text { with the existence of water } \\
\text { network, power grid, road network } \\
\text { connecting Surabaya - Sidoarjo. }\end{array}$} \\
\hline & With facilities & 5 & 5 & \\
\hline & Total & & 22 & \\
\hline
\end{tabular}

The highest value of each variable $=30$ and the lowest value was equal to 6 , included in the class of $30-6 / 3=8$ it was proper for the Rungkut industrial area.

Conformity class: very suitable (23-30) with high level of conformity.

Conformity class: suitable (15-22) with a high degree of conformity having a supporting factor for the industrial estate, an improvement in the supporting factors is made. 
Conformity class: inappropriate (6-14) with low level of conformity due to no supporting factor for industrial estate. Here is a thematic map for the parameters of location determination of warehousing coverage area of road network services. The assessment of land suitability level of warehousing to parameter (variable) determination of the Rungkut industrial area that is 22. SIER was considered appropriate for warehousing and industrial land.

\section{Application Design}

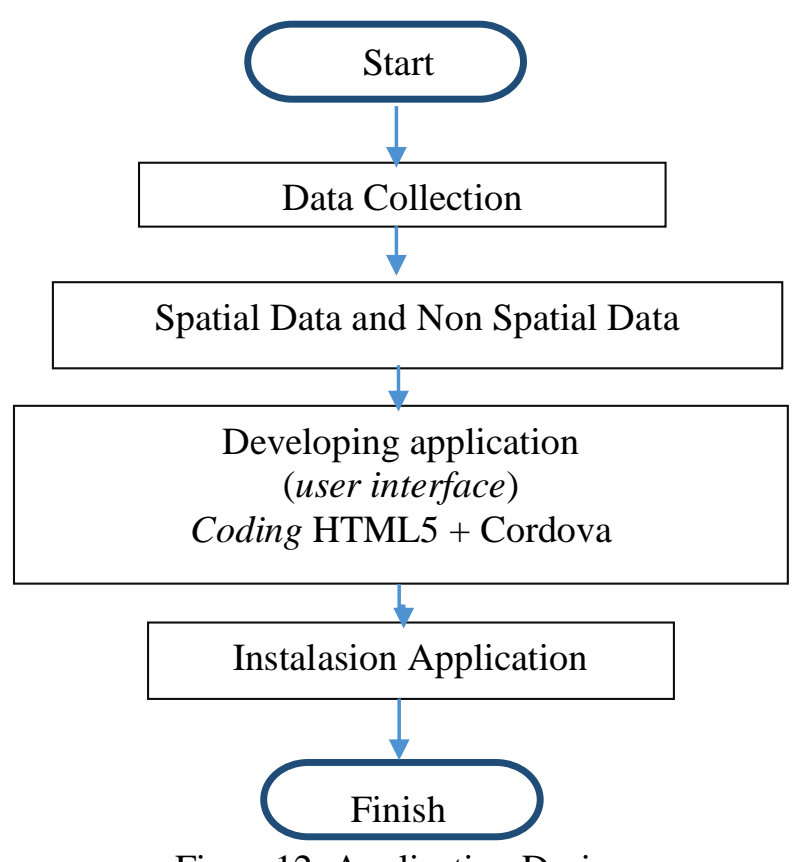

Figure12. Application Design

Geographical Information System Application Interface In the application interface SIG SIER will be explained about the use of applications starting from the user open the first application until each access can be obtained by the user Interface Aplikasi Sistem Informasi Geografis SIER (SIG SIER)

1. Main Page

This Main Menu is the start page that will be displayed when the user first opens the SIG SIER application. This page contains some menu that can be selected as needed. The menus listed on this page are legends, satellite imagery maps, and menus.

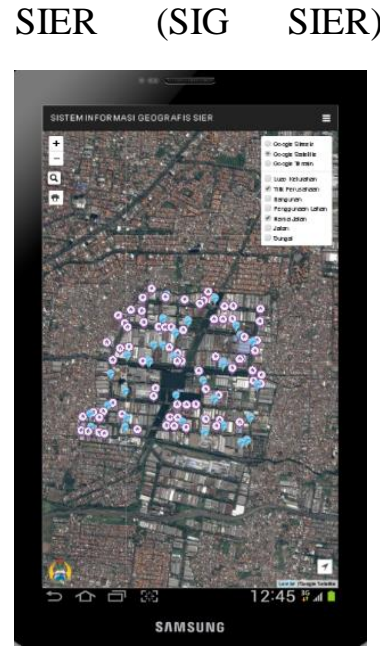

Figure 11. Main Page 


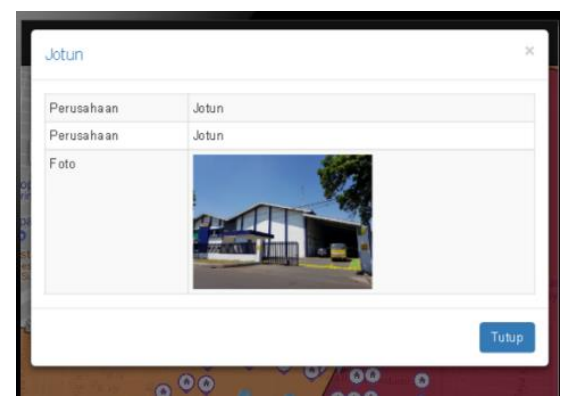

Choose a company point will appear the object information based on the coordinates of the results of field surveys.

Figure 13. Object

2. Menu buttons

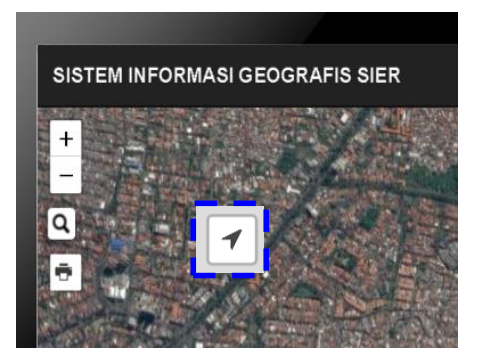

Button + zoom in map and - to zoom out the map area. Then search and print button. "My location" in the lower left corner serves to determine the position or location where the user is located.

Figure 14. Buttons

3. Legend menu content

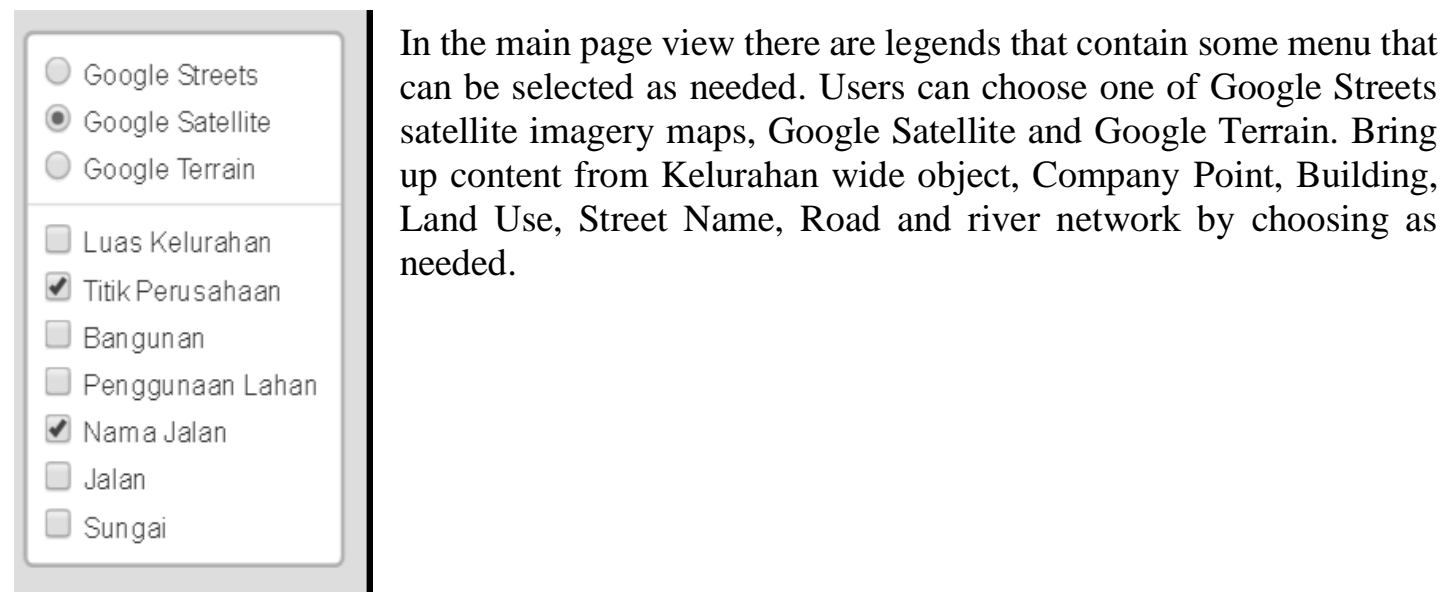

Figure 15. Legend

\section{About Menu}

The About menu on the main page of the app serves to display information about the SIG SIER application. The information shown among others is 

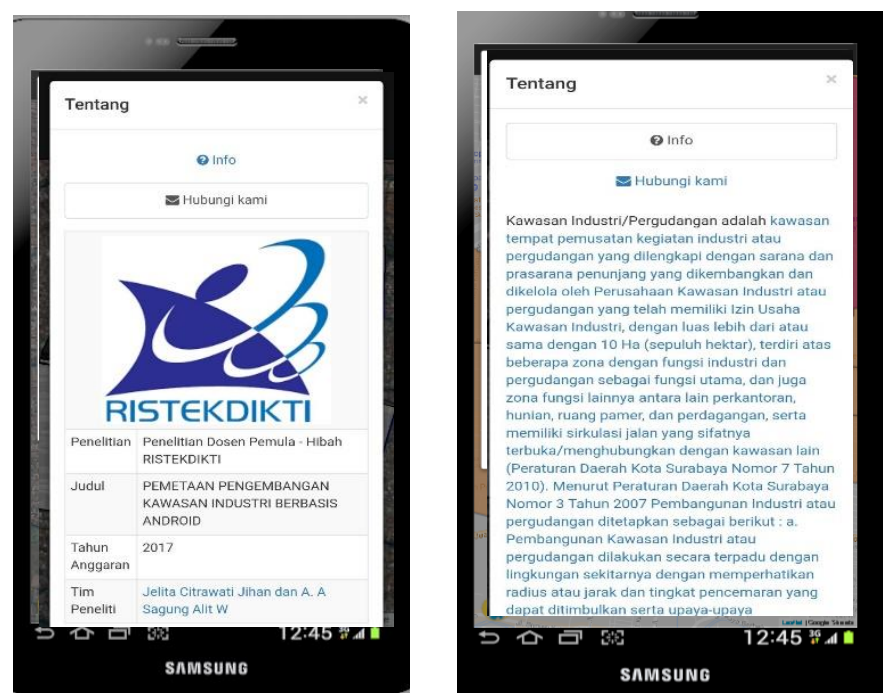

Figure 16. About Menu

\section{Conclusion}

From the calculations of accuracy of the existing map, there were 4 points of error from 19 points of field samples equal to $84.21 \%$ (acceptable) and fulfills tolerance above $80 \%$. The assessment of land suitability level of warehousing to parameter (variable) determination of the Rungkut industrial area was 22. It was therefore appropriate as industrial area. SIG SIER application is designed using HTML 5 and Cordova coding language to add geolocation and display Google Streets, Google Satellite and Google Terrain folders.

\section{References}

A. Journal Articles

Bambang, 2015, Pembuatan Aplikasi Mobile Gis Berbasis Android Untuk Informasi Pariwisata Di Kabupaten Gunungkidul. Kumpulan Jurnal Ilmiah Geodesi Undip, Vol. 4 No. 4. http://download.portalgaruda.org/article.php?article=321799. (retrieved on 1 May 2016)

Rushton, G. 2003, Public health, GIS, and spatial analytic tools Annual Review of Public Health;Department of Geography,the Universitiy of Iowa ; 24, ProQuest p. 43. Publhealth 24.012902.14843.

B. Report

Sholikhah, I. 2012. Evaluasi Kesesuaian Lahan untuk Kawasan Pergudangan di Wilayah Surabaya Timur Dengan Menggunakan Sistem Informasi Geografis. Thesis Geomatics ITS

Acknowledgements

The authors would like to thank the Ministry of Research, Technology and Higher Education of the Republic of Indonesia who has provided Grants for Beginner Lecturers to the authors. 
